\title{
ACADEMIC SOCIAL CAPITAL AND INSTITUTIONAL TRANSFORMATION OF ISLAMIC HIGHER EDUCATION IN INDONESIA
}

\author{
Nur Kafid \\ State Islamic Institute Surakarta \\ Pucangan, Kartasura, Sukoharjo, Central Java, Indonesia, 57168 \\ E-mail:mashafid@gmail.com
}

Arina Rohmatika

State Islamic Institute Surakarta

Pucangan, Kartasura, Sukoharjo, Central Java, Indonesia, 57168

E-mail:arinarohmatika@gmail.com

\begin{tabular}{c|c|c}
\hline Received: & Revised: & Approved: \\
12/08/2019 & $11 / 09 / 2019$ & $18 / 10 / 2019$ \\
\hline
\end{tabular}

DOI: http://dx.doi.org/

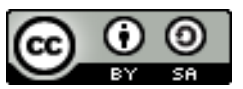

Academic Social Capital And Institutional Transformation Of Islamic Higher Education In Indonesia Licensed Under a Creative

Commons Attribution-ShareAlike 4.0 International License

\begin{abstract}
This study aims to see the potential and positioning of IAIN Surakarta, amid the trend of institutional transformation of Islamic Higher Education in Indonesia. In fact, transformation is not merely a matter of changing institutional status, but also the scientific quality of its civitas academics in responding to the technological developments and to the complexity of modern society's problems. Based on the qualitative approach, wherein the data is obtained from 10 key informants which are determined through the purposive sampling method, the results of this study show that institutional transformation requires the readiness of all resources as its academic social capital. Started from good and appropriate mapping, management and resource development, in accordance with the quality standards determined. However, all of these will not work well without comprehensive institutional policies. Policies that refer to the strategic
\end{abstract}


development plans, and completed with various rules, achievements, and indicators.

Keywords: Islamic higher education, and Institutional transformation

\section{A. Introduction}

Since the last decade, the institutional transformation of Islamic Higher Education (IHE) in Indonesia has seemingly become a 'trend'. The Islamic Higher Education institutions which previously only focused on developing Islamic knowledge, later on tended to be competing to integrate it with non-religious (secular) disciplines. Islamic courses have no longer stand alone, but being transplanted into public courses ${ }^{1}$. The scientific dichotomy (Islam and secular) starts to be abandoned ${ }^{2}$.

Consequently, besides being required to be able to integrate scientific traditions that will produce scholars who are experts in their fields and religiously charged 3 , or scholars who master science and have a solid foundation of faith and devotion, 4 IHE is also required to be able to respond to the technological developments and to the complexity of modern society ${ }^{5}$. The contribution of the output is also expected to have sustainability, not only related to academic issues but also in answering problems that develop in the society in general ${ }^{6}$. In other words, the output of IHE must be transformed into social-community life 7 .

1 Andi Wahyono, "Kebijakan Pendidikan Islam: Hibridasi Lembaga Pendidikan Tinggi," Jurnal Pendidikan Islam IIII, no. 1 (2014): 115-34, https://doi.org/10.14421/jpi.2014.31.115-134.

2 Syamsun Ni'am, "Menimbang Kembali Pendekatan Kajian Keislaman Di Perguruan Tinggi Agama Islam," Al-Tahrir2 11, no. 2 (2011): 349-70.

${ }^{3}$ Komaruddin Hidayat, Catatan Sewindu, Prestasi Dan Tantangan (Jakarta: IAIN Jakarta Press, 2010).

4 Syamsul Bahri, "Perubahan Paradigma Keilmuan IAIN Menuju UIN ArRaniry," Jurnal Ilmiah ISLAM FUTURA XI, no. 2 (2012): 38-52.

${ }^{5}$ Azyumardi Azra, Pendidikan Islam Tradisi Dan Modernisasi Menuju Milenium Baru (Jakarta: Logos Wacana Ilmu, 1999).

${ }^{6}$ Aam Abdussalam Syihabuddin, "Islamic Education: Its Concepts and Their Implementation in the Current Context," TARBIYA: Journal of Education in Muslim Society 2, no. 1 (2015): 23-34.

7 Muhammad Adib Abdushomad, "Improving Islamich Higher Education: Lessons From John Dewey and Ivan Illich," International Journal of Nusantara Is Lam 2, no. 1 (2014): 105-15. 
This condition has risen a new hope for IHE in Indonesia to be in aan equal position to the Universities abroad ${ }^{8}$. At the ASEAN level for example, Frank Dhont sees that the development of IHE in Muslimmajority countries (such as Brunei Darussalam, Malaysia, and Indonesia), besides being able to show pride in their traditions, also has a great opportunity to develop further along with the development of South-East Asian (ASEAN) Countries 9.

Despite of requiring a long process, this hope is definitely possible. If there are parties worrying about the existence and future of Islamic studies after the institutional transformation, the results actually show the opposite. Ar-Raniry State Islamic University (UIN) Ar-Raniry, Banda Aceh for example, after its institutional transformation, besides being able to offer more various disciplines of study to their prospective students, the existence of Islamic studies was even stronger ${ }^{10}$. The same phenomenon exists in UIN Maulana Malik Ibrahim, Malang, the success of institutional transformation is similarly in line with the strengthening and intensification of the implementation of the universality of Islamic values, both in the educational ${ }^{11}$ and social spheres ${ }^{12}$.

In this globalization era in which free market competition is increasingly high and economic growth is raising rapidly, transformation in the scientific field has become an inevitable demand. Universities, as the leading sector for improving the quality of human resources are also required to improve. Various policies for developing Universities, as an effort to produce competitive human resources, must also be a concern of policy holders. The policy that is able to attract the interest of prospective students to continue their studies at certain Universities is a priority. Given,

8 Ronald A. Lukens-Bull, Islamic Higher Education in Indonesia: Continuity and Conflict (New York: Palgrave Macmillan, 2013).

${ }^{9}$ Frank Dhont, "Islamic Higher Education in the Asean Region: Opportunities and Challenges," Jurnal Pendidikan Islam 2, no. 3 (2016): 379-92, http://dx.doi.org/10.15575/jpi.v2i3.865 ISLAMIC.

10 Fridiyanto, "The Transformation of UIN Ar-Raniry Banda Aceh: Opportunities and Challenges For Islamic Higher Education," Ta'dib: Journal of Islamic Education 22, no. 2 (2017): 21-43.

${ }^{11}$ Nur Kafid, “Ma'had Sebagai Role Model De-Radikalisasi," DINIKA: Journal of Islamic Studies 13, no. 2 (2015): 21-33.

12 Muhammad In'am Esha, “Universitasisasi STAIN Malang: Analisis Kebijakan Publik Perubahan Kelembagaan Dalam Perspektif Filsafat Nilai," Ulul Albab, Jurnal Studi Islam 13, no. 2 (2012): 1-20. 
how fundamental is the role of IHE and all its academic community in forming opinions and understanding the Indonesian Islamic community 13 .

The history of the success of institutional transformation of several IHE's in Indonesia has indeed been influenced or driven by many things. Starting from the political, socio-ideological side, institutions, the world of work, science, the development of the nation and state, global competition, the principle of openness, 14 and the existence of students: their backgrounds and decisions in choosing and determining University choices 15. One thing for sure, success requires a long and institutionalized process, careful planning in facing changes, and the basic principles of empowerment must be carried out more intensively to implement sustainable policies from continuous improvement programs as the core of empowerment management and quality improvement ${ }^{16}$.

Recently, Institute Agama Islam Negeri (IAIN) Surakarta as one of the IHEs in Indonesia also has the desire to transform institutionally into UIN. This desire certainly must be carried out by considering various potential opportunities, challenges, and threats, in addition to optimizing the strengths that have already have gotten. Not only administratively in the process of organizing education, but also human resources, curriculum, educational orientation, and various other related matters. Moreover, to be able to become a World Class University, it takes at least five (5) international standards that must be met by a IHE, starting from the principles of good governance, student affairs, teaching and learning processes, library and Information Technology, and reseaches and researchers ${ }^{17}$.

${ }^{13}$ Ronald A Lukens-bull, "The Political Use of Islamic Variation in Indonesian Islamic Higher Education," Jurnal Pendidikan Islam 2, no. 2 (2016): 193-207, http://dx.doi.org/10.15575/jpi.v2i2.786.

${ }_{14}$ Amiruddin, "Dinamika Lembaga Pendidikan Tinggi Islam," MIQOT XLI, no. 1 (2017): 98-117.

15 Shun Wing Ng Yin Cheong Cheng, Alan Chi Keung Cheung, "Internationalisation of Higher Education: Conceptualization, Typology and Issues," in Internationalization of Higher Education The Case of Hong Kong EDUCATION IN THE ASIA-PACIFIC REGION :, ed. Yin Cheong et al. (SIngapore: Springer, 2016), 1-18.

16 Fachruddin, "Manajemen Pemberdayaan Dalam Peningkatan Mutu Pendidikan Islam Di Indonesia," Ta'dib 12, no. 1 (2009): 49-56.

${ }_{17}$ M. Syamsul Huda, "Quantum Spirituality: Strategi UINSA Menuju World Class University," in UINSA EMAS Menuju World Class University, ed. Taufiq, 1st ed. (Surabaya: UIN SA Press, 2016), 1-8. 
All the requirements mentioned above, according to the researchers, constitute a unity that cannot be separated from each other, and must be fulfilled by IHE whereby desires to transform institutionally and aspire to become reputable Universities. To make it come true, IHE must firstly carry out a comprehensive mapping of the readiness of all resources owned as its academic social capital.

Indeed, there have been many previous studies showing the process of the journey and the success of institutional transformation of IHE in Indonesia, but can all those processes and stages that lead to fruitfulness can be applied to the context of IAIN Surakarta? Then how is the potential and positioning of the IAIN Surakarta itself in preparing its institutional transformation process? Here is the urgency of this study, so that the results are expected to be able to contribute institutionally, especially in the development of IAIN Surakarta to be UIN Surakarta, without having to be uprooted from its historical roots, local culture, and able to provide real contributions to scientific and community development, both at local, national, and international levels.

In order to produce comprehensive data, a qualitative approach is applied by researcher to describe social reality as a whole related to the experience of successful institutional transformation of other IHE (UIN Walisongo Semarang as parent/embryo of the emergence of IAIN Surakarta; and UIN Maulana Malik Ibrahim, Malang as IHE whose transformation process through leap process of institutional status); potential mapping and institutional positioning of IAIN Surakarta itself as its academic social capital towards institutional transformation. In-depth interviews with ten (10) key-informant were determined based on the purposive sampling method to be the way researchers obtained research data. Those informants are related parties or those who know various things related to academic and/or academic support in IAIN Surakarta, and other IHEs that have previously transformed into UIN (UIN Walisongo, Semarang and UIN Maulana Malik Ibrahim, Malang). In order to enrich and sharpen the analysis of the data obtained, observation (the relation of IAIN Surakarta and the surrounding community) and literature review from various sources, such as books, magazines, newspapers, and other sources related to the subject matter of the research were also carried out by researchers.

\section{Mapping the Social Capital}

The success of IHE's institutional transformation process in Indonesia is influenced by many factors. However, it does not need necessarily that all these factors can be recognized well from an early age. For this reason, 
mapping efforts are needed for various potentials that have already been owned, so that they can later be used as social capital towards the transformation process.

IAIN Surakarta, as IHE which is present in the midst of the people of Solo, a region that is culturally well known for being friendly, tolerant, and has a high Javanese cultural philosophy, has two main mandates that must be fulfilled ${ }^{18}$. First, the mandate as dakwah council; acting as an agent of Islamization, an institution that is expected to be able to spread the universal values of Islam in the framework of implementing education, teaching and community service. Second, the mandate as a place for developing science; held a Tridharma activity for higher education as an agent of social change.

From the perspective of structural functionalism 19, in which order becomes the main pressure point in an effort to reach a point of balance and conflict must be avoided in order to maintain the continuity of the existing social system. For this reason, institutional structures are needed in the mechanism to fulfill functional prerequisites to achieve certain structural types. Starting from the kinship structure (regulation of feeling expressions, maintenance, and education); structure of instrumental and stratification achievements (individual spirit in realizing shared prosperity); and territoriality (strength and integration); religion and value integration (system of values and commitment) ${ }^{20}$.

From the perspective of structural functionalism, in which orderliness is highlighted in an effort to reach a point of balance and conflict must be avoided in order to maintain the sustainability of the existing social system, each individual needs cultural values and social norms as a motivation. Thus, an institutional structure is needed in the mechanism to fulfill functional prerequisites to achieve certain structural types. Starting from the kinship structure (regulation of feeling expressions, maintenance, and education); structure of instrumental and stratification achievements (individual spirit in realizing shared prosperity); and territoriality (strength and integration); religion and value integration (system of values and commitment).

18 Nur Kafid \& Nur Rohman, "Islamic Higher Education and Religious Transformation of the Muslim Community's Surrounding," Jurnal Pendidikan Islam 4, no. 1 (2018): 27-38, https:// doi.org/10.15575/jpi.v4i1.2069.

19 George Ritzer, Sosiologi Ilmu Pengetahuan Berparadigma Ganda (Jakarta: Rajawali Pers, 1992).

20 Doyle Paul Johnson, Teori Sosiologi Klasik Dan Modern (Terj)., I (Jakarta: Gramedia Pustaka Utama, 1986). 
In this context, the formulation of the vision and mission of higher education institutions is expected to become a glue and institutionalized social control, as well as becoming a common platform in moving towards institutional transformation. In addition, from the formulation of the vision and mission, every individual in an institution will be motivated to move together to prepare a better institutional order, within the framework of shared welfare.

However, in order to ensure the continuity of joint commitments through the formulation of the vision and mission, critical concepts are needed in the interaction process. George Herbert Mead ${ }^{21}$ reminds that the interaction process can run and develop well if serious attention is focused on the following three (3) aspects; thoughts that arise and develop as an integral part of the social process (mind); communication between individuals dialectically with thoughts (self); and society (society). Because individual behavior (in a system) is strongly influenced and determined by situations, objects, and themselves, the importance of efforts to create conditions, objects, and situations that encourage each individual to have a (positive) interpretation of the transformation effort become urgent. Consequently, we need Bruce J. Cohen's 22 model and pattern of socialization that is oriented to (1) preparing the skills needed by each individual in the future; (2) effective communication skills; (3) familiarizing themselves with locality values; (4) forming an experience-based behavior system.

If the above conditions can be well created, it will become an academic social capital for the desired process of institutional transformation. Given that social capital is something that can build, strengthen and enrich relationships between individuals. Gaps that have the potential to separate parties who feel different from each other can be bridged. Existing differences can be managed well into strengths, instead of threats of division ${ }^{23}$.

Social capital can mean either good intentions available to each individual or group. The source is in the structure and content of social relations between actors. The effect then flows from information, influence, and solidarity available to the actor within the framework of creating

${ }^{21}$ George Ritzer \& Douglas J. Goodman, Teori Sosiologi Modern (Jakarta: Prenada, 2011).

22 Johnson, Teori Sosiologi Klasik Dan Modern (Terj).

23 Darmiyati Zuchdi Sri Sumarni, Achmad Dardiri, "The Development of Character Education Model Based on Strengthening Social Capital for Students of State Islamic University ( UIN ) Sunan Kalijaga," Journal of Education and Practice 6, no. 1 (2015): 13-23. 
internal and external ties between individual and collective actors so that in eventually, it can be mobilized to create a new bond 24. Thus, social capital is not only limited to aspects of social networks, but also the utility of social and network resources that affect the level of social resources within the network. In other words, individuals who have strong relationships tend to provide more information and assistance to other individuals. As a result, the value of social capital will depend on the nature of the contacts that make up social networks 25 .

\section{B. Institutional Potential of IHE}

The transformation of IHE institutions into UIN, of course requires thorough readiness and preparation not only administratively but also institutional substantive quality. From the success of the institutional transformation of Walisongo State Islamic University, Semarang and Maulana Malik Ibrahim State Islamic University, Malang, at least some institutional potentials have been successfully prepared (capitalized) as their social capital. Starting from resources, quality standards, and improving the quality of higher education.

\section{Resources}

Resources in this context, refer to not only Human Resources (HR), but also other resources owned by IHE. The quality of HR with the perfect role is the key. The unprepared HR will affect the transformation process. As a result, it is necessary to map the HR appropriately, according to their field of expertise. Moreover, it is necessary to synergize the role of HR, starting from conceptors, movers, and supporters of change.

Team solidity has been showed by UIN Maulana Malik Ibrahim, Malang in the process of institutional transformation. There was a division of works in the team, as a formulator of the model and quality of education, philosophical values, and the role of lobbying. This team created a communication room in the framework of building a shared vision and mission towards UIN (interview with Rosihan \& Hilmy, 11/03/2017). Through this communication space, updating the transformation progress and strengthening the sense of togetherness were created. The process of evaluating each stage would be discussed, in order to determine the next step, including finding alternative solutions if constraints are found.

24 Paul S Adler and Seok-woo Kwon, "Social Capital: Prospects for a New Concept," Academy of Management Review 27, no. 1 (2002): 17-40.

${ }^{25}$ SE Scott E Seibert, ML Maria L Kraimer, and RC Robert C Liden, "A Social Capital Theory of Career Success," Academy of Management Journal 44, no. 2 (2001): 219-37, https:/ / doi.org/10.2307/3069452. 
Although IHE feels that it has had sufficient human resources, without mapping made in accordance with their competencies and the work synergistic patterns, institutional transformation efforts will be difficult to realize. To be more specific, it can even potentially cause conflict. If a conflict arises, the existing energy will be depleted in efforts to resolve the conflict, instead of the transformation efforts (interview with Abdul Kholiq, 08/05/2017). Good HR and organization management become a prerequisite that cannot be ignored, because it is related to the fulfillment of quality standards and IHE graduates (interview with Abdul Muchayya, 08/05/2017).

Besides that, proper HR mapping can also foster HR self-creativity. Especially in the context of preparing a design for the management and development plan of the 'rare applicants' of unpopular disciplines of the study (interview with Lulu Choirunnisa, 08/05/2017). The reason is, this 'scarcity' may not be due to an unpopular disciplines of the study, but more on the non optimal managing and 'marketing' in the institution.

However, mapping and role synergy are not enough to foster HR creativity. It is necessary to grow a supportive, creative, innovative, and emotional leadership model. Leaders who dare to make decisions and make policy breakthroughs (interview with Rosihan \& Hilmy, 11/03/2017). Breakthroughs in the framework of developing the quality of human resources and other resources, including creativity in 'capitalizing' for the sake of progress and mutual prosperity institutionally.

\section{Quality Standards}

The quality standards that are used as references by Universities in Indonesia, including IHE are the standards set by the National Accreditation Board of Higher Education (BAN-PT). To meet this standard, each college is required to have a policy of quality that is tailored to the context and needs as a work reference.

Discussing about the policy of quality, it will definitely deal with the macro-institutional policies contained in the strategic plan (Renstra) for institutional development, complete with various rules, achievements, and achievement indicators. This strategic plan then becomes the institution's reference in carrying out each activity (interview with Abdul Kholiq, 08/05/2017). Thus, all performance achievements of the institution must be monitored and evaluated; starting from the planning, implementation, and performance forms based on predetermined instruments. Having the fact that this quality standard is dynamic, while the validity period of the strategic plan is only five (5) years, it is necessary to conduct a review process or even changes in every five (5) years. The process of reviewing or 
changing can only be conducted after firstly mapping the various potential risks that will possibly be faced, planning, dissemination, and implementation.

However, according to Abdul Muchayya (interview on 08/05/2017) the implementation of quality standards is not only a duty and responsibility of certain units or institutions in an institution, rather it becomes the task of the entire academic community. Starting from leaders at the University/Institute level, Faculties, and Departments, all teaching staff, all education staff, including all students. So this is where the synergy of understanding and work is needed related to quality standards that have been determined together. In the field of research, for example, researchers do not merely carry out research and make reports. They must provide the inclusion of quality standards. In other words, this quality standard must be integrated into the standards for the implementation of all higher education Tri Dharma activities (interview with Lulu Choirunnisa, 08/05/2017).

On the other hand, to ensure the process of implementing quality standards runs optimally, a clear control mechanism is needed. The mechanism that can be used as a benchmark for each stage of implementation and evaluation. What has been done by UIN Maulana Malik Ibrahim, Malang can be used as an example. Through the concept of scientific integration, UIN Maulana Malik Ibrahim, Malang applied the principle of synergy of steps and paradigms; between secular scientific and religious studies. As the result, there is no more dichotomy between secular and religious sciences. The case is that religious disciplines had been united or being united with the discipline of secular science (interview with M. Luthfi Mustofa, 11/03/2017). This was considered by the academics of UIN Maulana Malik Ibrahim, Malang as an answer to the emergence of concerns about the existence and sustainability of the sciencebased study program, after the opening of general science-based study programs.

The example of the scientific integration model implemented by UIN Maulana Malik Ibrahim, Malang, can be seen in the Islamic Economics department. Since the economic disciplines developed are Islamic economics, the subjects such as the Hadith and the Qur'an study are no longer a separate subject, but are integrated into the economic subjects.

Having been a guideline for implementing quality standards, this scientific integration model is the main pillar that must be understood by all academicians of UIN Maulana Malik Ibrahim, Malang. One of its actual steps, is that in the first semester, all students are required to take and must pass the tarbiyyah ulul albab course (interview with M. Luthfi Mustofa, 
11/03/2017). Through this course, students are expected to be able to understand that they are actually part of the UIN Maulana Malik Ibrahim, Malang so that they are able to understand and internalize vision and mission of their campus. Vision is not only limited to Jargon, but also internalized and externalized into the attitudes and actions of all civitas academicas of UIN Maulana Malik Ibrahim, Malang. From this, all the activities of the Tridharma of Higher Education are reflected in all the movements of the academicians of UIN Maulana Malik Ibrahim, Malang.

\section{E. Quality improvement}

If the resources have been mapped properly and correctly and the quality standard document has been established, then the next step is the a quality improvement strategy. Along with the rapid flow of change, the quality of higher education institutions must be continually improved, or else they will be left by the stake holders. There are at least three (3) important things as a fundamental strategy for improving the quality of higher education. namely, leadership commitment, improvement of the quality of human resources, and active involvement of stake holders.

Firstly, leadership commitment. This does not merely refer to the personal personality of certain individuals personally, but all elements of leadership collective-collegially. The commitment referred to refers to the importance of experience-based support for quality assurance personnel. In other words, a careful planning is needed for the implementation of the field of study, with the output target which is taking lessons from the experience of other universities that are of better quality, complemented by an action plan for implementing the results of the comparative studies in the targeted institution in order to create a strategic plan and synergic movement between units or institutions. Through this activity, the needs can be mapped which can support the improvement of the quality of the institution (interview with Abdul Kholiq, Abdul Muchayya \& Lulu Choirunnisa, 08/05/2017).

Secondly, improvement of the quality of human resources. For the sake of the success of the institutional transformation process, improving the quality of human resources is an inevitable necessity. Starting from a shared understanding of the context of change, mental readiness, and its paradigm. Because the target of transformation is not just a change of name, but also a change in performance and mindset (interview with Lulu Choirunnisa, 08/05/2017). So that the institution becomes ready to design, reposition, and relocate all available resources, facilities and infrastructure maps, and management of the institution. Moreover, the teaching staff, targeted to obtain training in the scientific integration paradigm and the 
method of internalizing the scientific integration paradigm during the teaching process, undeniably play an important part. Starting from the process of making Semester Learning Plans (RPS), learning strategies, up to learning evaluation. The output must be applicable in teaching, research and community service activities .

Thirdly, active involvement of stakeholders. The two fundamental strategies for improving the quality of higher education institutions above must be simultonously followed by active involvement of stakeholders. The existence and continuity of a university are not only determined by and from the internal circle of the academic community, but also by and from relevant university stakeholders. All college activities (education/teaching, research, and community service) can be oriented towards the implementation of the Institute's/University's vision and mission comprehensively (interview with Rosihan, Hilmy, Luthfi Mustofa, 11/03/2017). Thus, curriculum development and other institutional activities are aligned with / able to answer community needs, and the level of public trust in the campus also increases.

\section{F. Positioning of Institutional PTKI}

After various potential institutions have been well mapped, the next step towards institutional transformation is to determine the positioning of the college either in the local, national, and even global context. It aims at reaching a more focused institution development and is able to meet the needs of the community. In the next stage, this positioning will be a distinction for an isntitute or university functioned as a distinctive feature which can attract people to enroll their children to the Universtity.

A university's distiction does not come into being for granted. There are considerations such as social, economic, cultural and political conditions in which the University is situated. All the main instruments and supporters must be prepared to ensure the quality of higher education. Distinction itself is neither just something that is 'differentiating', nor merely a jargon, but a distinctive characteristic resulted from its quality. Thus, shared awareness of the importance of acceleration of change and quality is important. In other words, the changes occured not only emphasize on quantitative, but also qualitative aspects so that higher education can attract prospective students enroll. This will create spirit for a University to continue adjusting to the needs of the community. The success of UIN Maulana Malik Ibrahim, Malang and UIN Walisongo, Semarang in determining the distinction in the midst of the crush of other University competitors, is not only recognized by the internal campus but also by other campuses. Those two campuses, which previously were 
relatively unpopular, have become favourites and even references for the community.

\section{G. Potential and Positioning of IAIN Surakarta}

IAIN Surakarta, is one of the IHE in Indonesia which owns a vision of institutional transformation into UIN. Institutionally, being compared to the other two IHEs which are part of this study, UIN Walisongo, Semarang and UIN Maulana Malik Ibrahim, Malang, the conditions of Surakarta IAIN indeed still need improvement, synergy, and integration of all potential data and resources possessed by each unit and/or institution.

One of several strategies which has been done and is being done by IAIN Surakarta is increasing the number of the A rank accreditation for the department (interview with Muh Nashiruddin, 08/29/2017). In this context, various breakthroughs in institutional policies are demanded (not the sporadic ones) that lead to supporting the transformation process. In attempt to create right on the target policies and meet the needs, it is necessary to map in advance the various driving and inhibiting factors.

Having examined on the side of scientific transformation (transformation of knowledge) to the surrounding community, especially in terms of religion, the role of IAIN Surakarta can be clearly seen. The existence of IAIN Surakarta has succeeded in inspiring the surrounding community to be more pro-active in making efforts to change understanding, attitudes, and actions in terms of implementing the values and teachings of the Islamic religion ${ }^{26}$. However, the success has not been fully recorded and institutionalized. In other words, the role still tends to be 'sporadic' by individuals (both by its lecturers and students) who happened to be affiliated with IAIN Surakarta.

Functionally and structurally, the relationship between IAIN Surakarta and the surrounding community is relatively good. However, because it has not been fully institutionalized, the potential for the emergence of conflict will still be very high ${ }^{27}$. Morever, a more prominent relationship can be seen precisely from the economic side; residents feel that they get benefits along with the increasing number of students who need boarding houses/residences and other economic needs. While the kinship structure (in terms of maintenance); structure of instrumental and stratification achievements (the spirit of realizing shared prosperity); and territoriality (strength and integration); religion and value integration (system value and

${ }^{26}$ Rohman, "Islamic Higher Education and Religious Transformation of the Muslim Community's Surrounding."

27 Rohman. 
commitment) 28 are still low. The results of the researchers' observations showed that there are still quite high constraints on the need for expansion of the area and the low level of control of the community (not just being a supervisor, but should be an integral part) of the dynamics of student social interaction when off campus.

At this point, the urgency of mutual understanding of critical concepts in the process of interaction ${ }^{29}$ between institutions and stakeholders are being urgent. The concept which is based on institutional vision and mission enables the conditions, objects, and situations to encourage each individual to have a (positive) interpretation of the transformation effort. The socialization format refers to the orientation of provisioning, based on effective communication by emphasizing understanding locality values as a shared learning experience ${ }^{30}$. As the result, the gaps that potentially trigger conflict can be bridged. Furthermore, the existing differences can be managed well into strengths, instead of threats of division ${ }^{31}$.

However, what should be noted is that the success of the institutional transformation process of UIN Maulana Malik Ibrahim, Malang and UIN Walisongo, Semarang are not merely because of the programs they have. The expertise and success of the transformation team, especially in "capitalizing" various potential resources possessed as symbolic strength in the public sphere, is also an important key driver of that success so that it also becomes legitimacy as well as academic "feasibility" social capital to transform into a State Islamic University. However, this symbolic 'capitalization' model must be followed by supporting evidence such as the increasing number of academic works and publications and the existence of reputable campus Scientific Journals (interview with Luthfi Mustofa, 11/03/2017).

Although IAIN Surakarta still needs optimization, it has owned an undeniable great potential in terms of academic social capital. The things is that how can the potential of social capital be 'capitalized' symbolically so that it can color and contribute to the public space as an excellence of the institution. This condition certainly will not be that easy to create. It is necessary to strengthen the structure and content of social relations between actors within the institution, in order to bring about a collective

28 Johnson, Teori Sosiologi Klasik Dan Modern (Terj).

${ }^{29}$ George Ritzer, Sosiologi Ilmu Pengetahuan Berparadigma Ganda (Terj.) (Jakarta: Rajawali Press, 1992).

${ }^{30}$ Johnson, Teori Sosiologi Klasik Dan Modern (Terj).

31 Sri Sumarni, Achmad Dardiri, “The Development of Character Education Model Based on Strengthening Social Capital for Students of State Islamic University ( UIN ) Sunan Kalijaga." 
bond between individuals, both internally and externally so that in the end it can be mobilized to create a new bond 32 . Indeed, the value of social capital is greatly determined by the nature of the contacts that make up the social networks 33 .

\section{H. Conclusion}

The process of institutional transformation is definitely not an instant process. Time and hard work are required to make it happen. Readiness of all resources needs to be well mapped and perfectly planned. Even though the availability of human resources is the main key, without precise mapping, management and development it can even be a barrier. In addition, institutional policies refering to the formulated strategic plans are also needed. The leaders' commitment to synergize all potential resources is a supporting prerequisite. Through this, institution's distinction will be not only found and shaped, but also 'capitalized' as a main reference for the public either in determining study choices, as well as in an effort to resolve various social-community problems so that the social relations which have been built with stakeholders are no longer sporadic (individually), but institutionally.

\section{REFERENCES}

Abdushomad, Muhammad Adib. "Improving Islamich Higher Education: Lessons From John Dewey and Ivan Illich." International Journal of Nusantara Is Lam 2, no. 1 (2014): 105-15.

Adler, Paul S, and Seok-woo Kwon. "Social Capital: Prospects for a New Concept." Academy of Management Review 27, no. 1 (2002): 17-40.

Amiruddin. "Dinamika Lembaga Pendidikan Tinggi Islam." MIQOT XLI, no. 1 (2017): 98-117.

Azra, Azyumardi. Pendidikan Islam Tradisi Dan Modernisasi Menuju Milenium Baru. Jakarta: Logos Wacana Ilmu, 1999.

Bahri, Syamsul. "Perubahan Paradigma Keilmuan IAIN Menuju UIN ArRaniry." Jurnal Ilmiah ISLAM FUTURA XI, no. 2 (2012): 38-52.

Dhont, Frank. "Islamic Higher Education in the Asean Region: Opportunities and Challenges." Jurnal Pendidikan Islam 2, no. 3 (2016): 379-92. http://dx.doi.org/10.15575/jpi.v2i3.865 ISLAMIC.

Esha, Muhammad In'am. “Universitasisasi STAIN Malang: Analisis Kebijakan Publik Perubahan Kelembagaan Dalam Perspektif Filsafat Nilai." Ulul Albab, Jurnal Studi Islam 13, no. 2 (2012): 1-20.

32 Adler and Kwon, "Social Capital: Prospects for a New Concept."

33 Seibert, Kraimer, and Liden, "A Social Capital Theory of Career Success." 
Fachruddin. "Manajemen Pemberdayaan Dalam Peningkatan Mutu Pendidikan Islam Di Indonesia." Ta'dib 12, no. 1 (2009): 49-56.

Fridiyanto. "The Transformation of UIN Ar-Raniry Banda Aceh: Opportunities and Challenges For Islamic Higher Education." Ta'dib: Journal of Islamic Education 22, no. 2 (2017): 21-43.

Goodman, George Ritzer \& Douglas J. Teori Sosiologi Modern. Jakarta: Prenada, 2011.

Hidayat, Komaruddin. Catatan Sewindu, Prestasi Dan Tantangan. Jakarta: IAIN Jakarta Press, 2010.

Huda, M. Syamsul. “Quantum Spirituality: Strategi UINSA Menuju World Class University." In UINSA EMAS Menuju World Class University, edited by Taufiq, 1st ed., 1-8. Surabaya: UIN SA Press, 2016.

Johnson, Doyle Paul. Teori Sosiologi Klasik Dan Modern (Terj). I. Jakarta: Gramedia Pustaka Utama, 1986.

Kafid, Nur. "Ma'had Sebagai Role Model De-Radikalisasi." DINIKA: Journal of Islamic Studies 13, no. 2 (2015): 21-33.

Lukens-Bull, Ronald A. Islamic Higher Education in Indonesia: Continuity and Conflict. New York: Palgrave Macmillan, 2013.

Lukens-bull, Ronald A. "The Political Use of Islamic Variation in Indonesian Islamic Higher Education." Jurnal Pendidikan Islam 2, no. 2 (2016): 193-207. http://dx.doi.org/10.15575/jpi.v2i2.786.

Ni'am, Syamsun. "Menimbang Kembali Pendekatan Kajian Keislaman Di Perguruan Tinggi Agama Islam." Al-Tahrir2 11, no. 2 (2011): 349-70.

Ritzer, George. Sosiologi Ilmu Pengetahuan Berparadigma Ganda. Jakarta: Rajawali Pers, 1992.

- - -. Sosiologi Ilmu Pengetahuan Berparadigma Ganda (Terj.). Jakarta: Rajawali Press, 1992.

Rohman, Nur Kafid \& Nur. "Islamic Higher Education and Religious Transformation of the Muslim Community's Surrounding." Jurnal Pendidikan Islam 4, no. 1 (2018): 27-38. https://doi.org/10.15575/jpi.v4i1.2069.

Seibert, SE Scott E, ML Maria L Kraimer, and RC Robert C Liden. “A Social Capital Theory of Career Success." Academy of Management Journal 44, no. 2 (2001): 219-37. https:// doi.org/10.2307/3069452.

Sri Sumarni, Achmad Dardiri, Darmiyati Zuchdi. "The Development of Character Education Model Based on Strengthening Social Capital for Students of State Islamic University ( UIN ) Sunan Kalijaga." Journal of Education and Practice 6, no. 1 (2015): 13-23.

Syihabuddin, Aam Abdussalam. "Islamic Education: Its Concepts and Their Implementation in the Current Context." TARBIYA: Journal of Education in Muslim Society 2, no. 1 (2015): 23-34. 
Wahyono, Andi. "Kebijakan Pendidikan Islam: Hibridasi Lembaga Pendidikan Tinggi." Jurnal Pendidikan Islam IIII, no. 1 (2014): 115-34. https://doi.org/10.14421/jpi.2014.31.115-134.

Yin Cheong Cheng, Alan Chi Keung Cheung, Shun Wing Ng. "Internationalisation of Higher Education: Conceptualization, Typology and Issues." In Internationalization of Higher Education The Case of Hong Kong EDUCATION IN THE ASIA-PACIFIC REGION:, edited by Yin Cheong, Cheng Alan, Chi Keung, Cheung Shun, Wing $\mathrm{Ng}$, The Case, and Hong Kong, 1-18. SIngapore: Springer, 2016. 
352 AKADEMIKA: Jurnal Pemikiran Islam

Vol. 24, No. 02 July - December 2019 